\title{
Epidemiological and dietary aspects of rickets and osteomalacia
}

\author{
By JoAn M. L. Stephen, Department of Health and Social Security and Human \\ Nutrition Studies Group, London School of Hygiene and Tropical Medicine, \\ London $W C_{\mathrm{I}}{ }_{7} H T$
}

\section{Historical introduction}

Rickets is not a fatal disease and therefore is not listed in the World Health Organization classification of diseases, so that it is difficult, if not impossible, to make accurate estimates of its prevalence. However, this was not always so, since in the $17^{\text {th }}$ century it was listed in the Bills of Mortality as one of the causes of death in the cities of London and Westminster, although the actual values given for this period are probably not very reliable because of the confusion with other diseases of the time. But at least it was a recognized disease. A detailed monograph on it was written by Glisson (1650), which more than $25^{\circ}$ years later was praised by Findlay \& Ferguson (1918) for the accuracy and thoroughness of the clinical and pathological descriptions. Glisson's book and other writings of that time indicated that the disease occurred in children in the first years of life, was very severe, producing gross deformities, and was frequently fatal. It was so prevalent that it became known on the continent of Europe as the English disease. Nevertheless it also existed throughout the more northern countries of Europe and particularly in The Netherlands. The Flemish painters of the 16 th and 17 th centuries are said to have painted the infant Christ from models with frank rickets, and Dick (1922) names some artists whose paintings in the National Gallery (London) show rachitic children. However, it is difficult to find an example of this.

At this period rickets was regarded as a disease of the upper classes. Children of the wealthy were covered in voluminous clothes and kept indoors in dark, badly ventilated houses, eating rich food, while the children of the poor were often running about in the fields exposed to the light and air. It was only with the growth of the great industrial cities that rickets became associated with overcrowded living conditions and a poor diet.

In 1888 a committee of the British Medical Association looked into the distribution of rickets in Britain and found it most prevalent in the big industrial centres and particularly in the coal-mining areas (Owen, 1889). Following this, Palm, who had been living in Japan for a number of years, in 1890 sent a questionnaire to medical missionaries in China, Japan, India, Ceylon and Morocco enquiring about the incidence of rickets. The replies showed that rickets was almost unknown even in the densely populated regions. This was attributed 
entirely to the effect of tropical sunlight, since diseases other than rickets were common and the diet in many of the areas was poor (Palm, 1890).

At the beginning of this century there were two schools of thought as to the cause of rickets: one blamed the poor quality of the diet, and the other bad ventilation and lack of hygiene. Cod-liver oil had been known for some time to be an effective cure for rickets. The discovery of vitamins and the work of Mellanby (1921) enabled the anti-rachitic agent to be recognized, and it was Dame Harriette Chick's work in Vienna after the First World War which identified the link between the curative effect of cod-liver oil and irradiation by sunlight and ultraviolet light (Chick, Dalyell, Hume, Mackay, Henderson Smith \& Wimberger, 1923).

With the discovery of vitamins and the realization that rickets was a vitamindeficiency disease, there seemed no reason why the disease should not be eliminated. Fortification of certain foods with ergocalciferol and the provision of cod-liver oil as a welfare measure did indeed reduce the incidence to almost negligible levels. Even after the reduction in 1957 of the amount of ergocalciferol added to welfare milks because of the occurrence of hypercalcaemia, the British Paediatric Association (1964) reported that the few cases of rickets ( $1 \cdot 5 /$ month) found by paediatricians in $1960-1$ in non-immigrants was an indication that the vast majority of infants were protected from the disease. However, they recognized that it could be a hazard to the immigrant population. In the years immediately following, the work of Arneil in Glasgow (Arneil \& Crosbie, 1963) and Stroud and his colleagues in London (Benson, Stroud, Mitchell \& Nicolaides, 1963) demonstrated that rickets was indeed a real problem in this group.

\section{Epidemiological aspects}

The reappearance of rickets in infants and young children in the early I960s drew attention to the possibility of vitamin $\mathrm{D}$ deficiency occurring in other vulnerable groups, and as we have heard in earlier papers in this symposium, milder conditions of muscular weakness and pains in the limbs are now regarded as manifestations of vitamin $\mathrm{D}$ deficiency, since they respond to treatment with vitamin D.

The milder a disease becomes, the more difficult it is to diagnose. This is possibly the reason why the Hospital In-Patients Enquiry up to 1967 included in its estimates of discharges from hospitals in England and Wales the headings 'active rickets', 'late effects of rickets' and 'osteomalacia', but, from I 968 onwards, combined the categories under the heading 'vitamin D deficiency' (Department of Health \& Social Security \& Office of Population Censuses and Surveys, 1970, 1974). Under this heading it can be seen that the number of cases has almost doubled over the past 5 years (Table $\mathrm{I}$ ).

In recent years the Department of Health \& Social Security has been much concerned about the problem of subclinical vitamin D deficiency (Department of Health \& Social Security, 1970). By definition this implies that no clinical signs are 
Table I. Estimated total discharge from hospitals in England and Wales of patients with rickets, osteomalacia or vitamin $D$ deficiency*

\begin{tabular}{lrrrrrrrrrr} 
Year . . & 1958 & 1959 & 1960 & 1961 & 1962 & 1963 & 1964 & 1965 & 1966 & 1967 \\
Active rickets & 100 & 50 & 120 & 110 & 160 & 190 & 150 & 220 & 90 & 120 \\
Late effects of rickets & 0 & 20 & 20 & 50 & 40 & 10 & 0 & 10 & 30 & 10 \\
Osteomalacia & 70 & 130 & 100 & 90 & 150 & 160 & 230 & 210 & 220 & 130 \\
Total & 170 & 200 & 240 & 250 & 350 & 360 & 380 & 440 & 340 & 260 \\
\hline Year . . . & 1968 & 1969 & 1970 & 1971 & 1972 & & & & & \\
Vitamin D deficiency & 363 & 572 & 421 & 675 & 633 & & & & &
\end{tabular}

-From Department of Health \& Social Security \& Office of Population Censuses and Surveys (1970, 1974).

available for diagnosis, and the absence of precise clinical criteria has meant a dependence on radiological and biochemical evidence. It is not nowadays considered ethical to use $\mathrm{X}$-rays without justification, so that biochemical measurements are increasingly used for the diagnosis of rickets. The classic biochemical indication of rickets is an increase in the activity of serum alkaline phosphatase (EC 3.1.3.1) sometimes, but not always, accompanied by a decrease in the concentration of serum calcium. However, there is some doubt as to the reliability of the alkaline phosphatase measurement, since the activity of the enzyme can be increased for reasons other than bone disease and the limits of values which can be regarded as normal are undecided. In $197 \mathrm{I}$, following reports, based largely on biochemical evidence, of the recurrence of rickets in young children, Stephen \& Stephenson (1971) attempted to establish a range of values of alkaline phosphatase for children who were protected from the risk of nutritional rickets. These were either immigrant or non-immigrant children in London daynurseries who were receiving vitamin D supplements, or West Indian children of the same age exposed to tropical sunlight in their own country. Values above those generally accepted as normal occurred in all the groups of children (Fig. I), and some exceptionally high values returned to the usual range without any treatment. This same phenomenon of transient high values has been observed by other authors (Asanti, Hultin \& Visakorpi, I966; Richards, Hamilton, Taylor, Sweet, Bremner \& Price, I 968 ).

Another feature emerges from this survey: $40 \%$ of the children in the London day-nurseries were coloured immigrants, mostly West Indians. The distribution of their alkaline phosphatase values corresponds almost exactly to that of West Indian children in their own country and shows a peak at a higher value than that of the white children (Fig. 2). Attention has been drawn to the difference in distribution of alkaline phosphatase values in Asian and Caucasian children (Holmes, Enoch, Taylor \& Jones, 1973) in Rochdale. It is possible that there is some genetic difference in the alkaline phosphatase values between coloured and non-coloured people, and this should be taken into account when comparing values in different ethnic groups. 


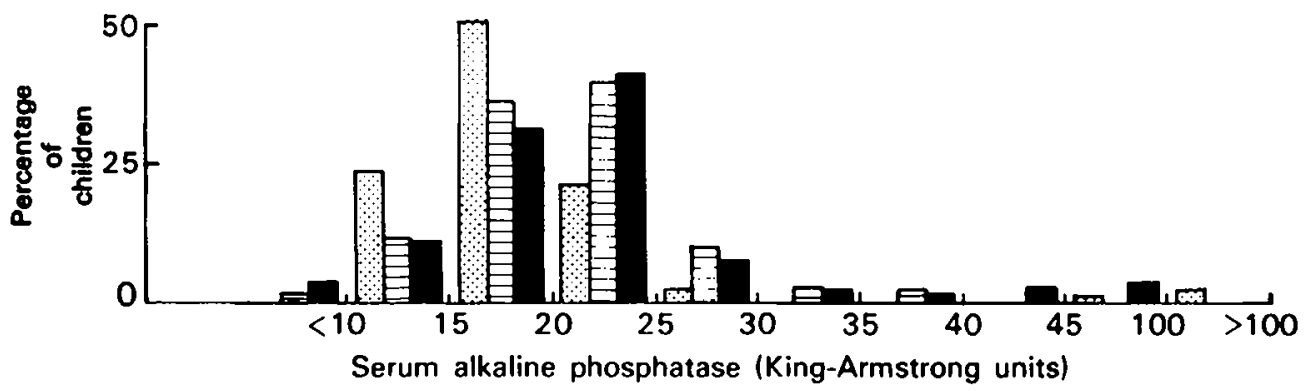

Fig. 1. Distribution of serum alkaline phosphatase (EC 3.1.3.1) levels (King-Armstrong units; King \& Armstrong, 1934) in immigrant and non-immigrant children aged 1-2 years in London daynurseries and in West Indian children of the same age in the West Indies. 国, Non-immigiant children in UK; $\mathbf{0}$, immigrant children in UK; $\mathbf{0}$, West Indian children in the West Indies.

Until now, therefore, the diagnosis of rickets by biochemical means has been only moderately successful. It may be that with the introduction of a method for measuring the vitamin D metabolite, 25-hydroxycholecalciferol $(25-\mathrm{HCC})$, in serum or plasma, we shall have a more direct and more efficient tool for the purpose. This still needs some validation with clinical and radiological evidence and some development of the method to make it suitable for use on a survey scale. Even then, the fact remains that it is not considered ethical by some to take blood samples randomly from children without some reason to believe they are at risk. Therefore, for epidemiological purposes, we are thrown back on clinical signs and symptoms which are obvious without either taking blood samples or X-rays. It remains a difficult problem to resolve.

\section{The problem overseas}

While we are becoming more aware of a problem of rickets amongst the immigrant population in this country, more reports reach us of rickets and osteomalacia in the countries from which the immigrants come. Vaishnava \& Rizvi (1967), for example, stated that in New Delhi three to four new cases of osteomalacia

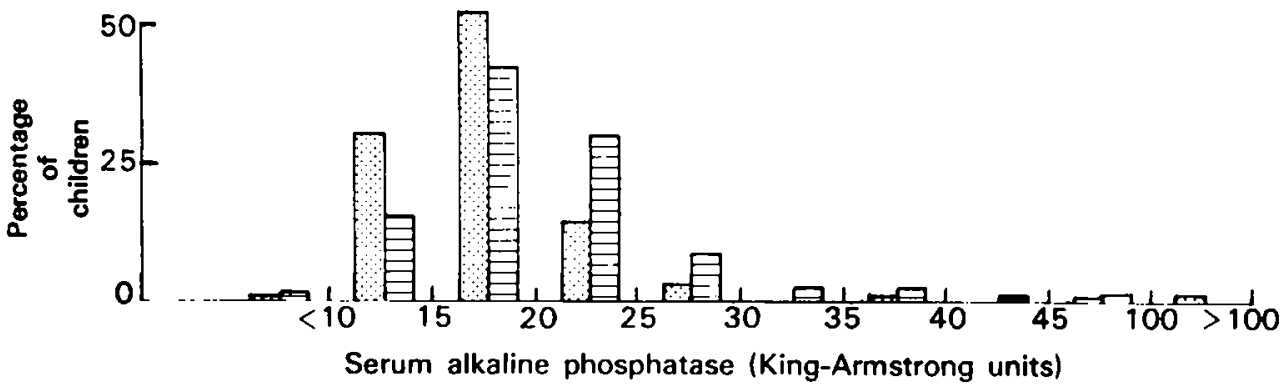

Fig. 2. Distribution of serum alkaline phosphatase (EC 3.1.3.1) levels (King-Armstrong units; King \& Armstrong, 1934) in immigrant and non-immigrant children aged $1-3$ years in London daynurseries. to, Non-immigrant children; 目, immigrant children. 
were discovered in a week in the out-patient department and that more than sixty cases of advanced osteomalacia were admitted to hospital per year. Agrawal, Sheth \& Tibrewala (1969) described a study of 300 cases of children with rickets in Bombay. In fact, a search of the literature reveals that rickets has been by no means unknown in parts of India since the end of the First World War. Wilson \& Widdowson (1942) give many references to earlier work there and describe the various aspects of the disease which they themselves saw.

Why then did the belief exist that in tropical countries rickets did not constitute a problem? I think there may be a number of explanations. First, there may be a parallel with the disease kwashiorkor, which was first described by Williams (1933), and during the next 20 years was recognized and described in more and more countries of the world where hitherto it had been unnoticed (Waterlow, Cravioto \& Stephen, 1960). Secondly, rickets used to be a disease of early childhood. The infant mortality in countries such as India was so high that a large proportion of children died; if they survived, their condition of life improved in that they could then benefit from the open air and sunlight. Thirdly, it has been observed that rickets does not occur in the presence of malnutrition: when children do not grow they do not develop rickets (Waterlow \& Vergara, 1956).

Many of the countries which we tend to regard as enjoying continual tropical sunlight often have very cold winters as well, when children, if they go outdoors at all, are well wrapped up. In Iran, for example, (Salimpour, 1975) there is a seasonal pattern to admissions to hospital of children with radiological rickets very similar to the variation in serum 25-HCC levels found by Gupta, Round \& Stamp (1974) at different times of the year. In Morocco an increase at the end of the winter in the number of children with signs of rickets was also found by Guignard, Belkziz \& Belhaj (1971). This supports the idea that lack of sunlight, combined with an inadequate intake of vitamin $\mathrm{D}$, is an important cause of the disease.

\section{Dietary aspects}

There are comparatively few foods which naturally contain vitamin D. Milk, butter, cheese and eggs are the main ones but their content is small. The most important source in the diet would be fatty fish such as herrings or sardines, or margarine which is artificially fortified with ergocalciferol. Young children also receive additional vitamin $D$ from the fortified dried milks and cereals. Rickets in infants and very young children, particularly immigrants, has been explained on the grounds that they are either breast-fed for extended periods without supplementation with extra vitamin D or fed on liquid cow's milk (Stroud, 1971). Cow's milk is a poor source of the vitamin, containing about $0.25 \mu \mathrm{g}$ cholecalciferol/1, but varying according to the season of the year. The amount present in cow's milk alone is clearly not enough to meet the recommended intake, which is $10 \mu \mathrm{g}$ cholecalciferol $/ \mathrm{d}$ for children up to the age of 5 years and $2.5 \mu \mathrm{g} / \mathrm{d}$ thereafter (Department of Health \& Social Security, 1969). Cod-liver oil, which used to be available as a supplement in welfare clinics, has been replaced by drops, 
containing retinol, ascorbic acid and cholecalciferol, a single dose of which contains the recommended daily intake.

A dietary survey done on children up to 5 years old in Britain has shown average daily cholecalciferol intakes well below the recommended level, that is, of the order of $2.5 \mu \mathrm{g}$ (Ministry of Health, 1968 ). In another survey of a random sample of older children, Cook, Altman, Moore, Topp, Holland \& Elliott (1973) found that on average the intake met the recommended level of $2.5 \mu \mathrm{g} / \mathrm{d}$ for all groups except

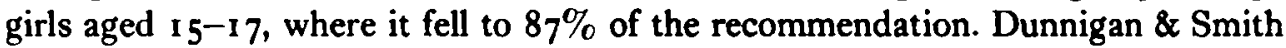
$(1965)$ also found intakes of about $1 \cdot 7-2 \cdot 0 \mu \mathrm{g} / \mathrm{d}$ and not a great deal of difference between European and Pakistani children or between children with and those without rickets. Similar intakes were found by Ruck (1973) in a dietary survey of Asian, European and West Indian schoolchildren. However, Ruck found that the West Indians ate about four times as much margarine in their diets as the other two groups and therefore their intake of vitamin $\mathrm{D}$ was markedly higher than that of the Asians or the Europeans (Table 2). This perhaps follows from the fact the West Indian children came from larger families than the other children, and, according to the National Food Survey Committee (1970), the consumption of margarine per person is greater in larger families. West Indians do not appear to be as susceptible as Asians to rickets and the vitamin D they obtain from margarine may help to protect them. Asians probably do not change their traditional dietary habits as easily as West Indians.

Table 2. Daily intakes of energy, vitamin D, calcium and phytate by Asian, West Indian and European children $\dagger$

(Mean values and standard deviations)

\begin{tabular}{|c|c|c|c|c|c|c|c|c|c|c|}
\hline \multirow[b]{3}{*}{ Group } & \multirow[b]{3}{*}{ No. } & \multicolumn{4}{|c|}{ Energy } & \multirow{2}{*}{\multicolumn{2}{|c|}{$\underset{(\mu \mathrm{g})}{\text { Vitamin }} \mathrm{D} \ddagger$}} & \multirow{2}{*}{\multicolumn{2}{|c|}{$\underset{(\mathrm{mg})}{\mathrm{Ca}}$}} & \multirow{2}{*}{$\begin{array}{c}\text { Phytate } \\
\text { (mg) }\end{array}$} \\
\hline & & $\mathbf{M}$ & & kc & & & & & & \\
\hline & & Mean & sD & Mean & sD & Mean & SD & Mean & SD & Mean SD \\
\hline $\begin{array}{l}\text { All children } \\
\text { Isians } \\
\text { Nest Indians } \\
\text { Europeans }\end{array}$ & $\begin{array}{l}47 \\
22 \\
11 \\
14\end{array}$ & $\begin{array}{l}9.07 \\
8.95 \\
8.49 \\
9.61\end{array}$ & $\begin{array}{l}2 \cdot 55 \\
2 \cdot 93 \\
2 \cdot 13 \\
2 \cdot 59\end{array}$ & $\begin{array}{l}2170 \\
2140 \\
2030 \\
2300\end{array}$ & $\begin{array}{l}610 \\
700 \\
510 \\
620\end{array}$ & $\begin{array}{l}1 \cdot 70 \\
1 \cdot 50 \\
1 \cdot 80 \\
1 \cdot 60\end{array}$ & $\begin{array}{l}1 \cdot 20 \\
1 \cdot 20 \\
1 \cdot 30 \\
1 \cdot 00\end{array}$ & $\begin{array}{l}780 \\
850 \\
540 \\
780\end{array}$ & $\begin{array}{l}310 \\
330 \\
240^{\circ} \\
260\end{array}$ & $\begin{array}{ll}160 & 130 \\
230 & 140^{\circ} \\
80 & 30 \\
90 & 40\end{array}$ \\
\hline
\end{tabular}

Values significantly different from those for European children: $\bullet P<0.01,{ }^{\bullet \bullet P}<0 . \infty 1$. †From Ruck (1973).

$\ddagger$ As cholecalciferol equivalents.

$\mathrm{Ca}$ is another important dietary factor in the consideration of rickets. It is derived mainly from milk and milk products such as cheese, from cereals and from flour, to which it is added artificially. Phytic acid, which is present in wholemeal flour, can complicate the absorption of $\mathrm{Ca}$ by forming an insoluble salt. In the ordinary English diet phytic acid is partly destroyed by the action of the phytase (myo-inositol hexaphosphate phosphohydrolase; EC 3.1.3.8) of yeast during the process of bread-making, but an important item in the diets of Asians is the 
chupatty, which is made from flour without the action of yeast. In recent years, when attention has been directed to the rickets of adolescents and the osteomalacia of Asian pregnant women, the importance of chupatties in the diet has been investigated. There have been conflicting reports about this: Dunnigan \& Smith (1965) concluded that rickets and osteomalacia of Indian and Pakistani subjects was unrelated to the phytate content of their diet, but when Ford, Colhoun, McIntosh \& Dunnigan (r 972) gave ten Pakistanis with rickets or osteomalacia a diet which excluded chupatties, they found a biochemical response which suggested healing of the bone disease. On the other hand, a high phytate intake from four is automatically accompanied by a high $\mathrm{Ca}$ intake because of the fortification of flour with $\mathrm{Ca}$, and in the diets of the Asian boys studied by Ruck (1973), milk also contributed to a high Ca intake. It was unlikely that the phytate could have had any appreciable effect on this level of $\mathrm{Ca}$ intake. This finding has been confirmed by E. M. Widdowson \& A. J. O'Hara-May (unpublished results) in a study on a group of Asian boys of similar age.

Diet cannot be isolated from other environmental factors, particularly in the instance of vitamin D, which the body obtains from the action of light on the skin as well as from the diet. Social customs, such as those of the Asians, the seclusion of their womenfolk and their dress, must play a part. West Indian children in this country have a mode of life much more like that of European children. The importance of sunlight has already been stressed, and even the difference in the amount of sunlight between the north and the south of Britain may explain why nearly all the reports of rickets and osteomalacia have come from northern sources. This may affect not only the immigrant population but also the elderly housebound, who may have a low dietary intake of vitamin D. Our own habits and environmental conditions change too. Living in high-rise blocks of flats may mean less exposure for babies, and girls nowadays wearing trousers rather than miniskirts, both girls and boys with long hair shading their faces and young people generally with fewer outdoor pursuits may well have the effect of lowering vitamin D status.

\section{REFERENCES}

Agrawal, J. R., Sheth, S. C. \& Tibrewala, N. S. (1969). Indian Pediat. 6, 792. Ameil, G. C. \& Crosbie, J. C. (1963). Lancet ii, 423 . Asanti, R., Hultin, N. \& Visakorpi, J. K. (1966). Annls Paediat. Fenn. 12, 139.

Benson, P. F., Stroud, C. E., Mitchell, N. J. \& Nicolaides, A. (1963). Br. med. F. i, 1054. British Paediatric Association (1964). Br. med. F. i, 1659 .

Chick, H., Dalyell, E. J., Hume, E. M., Mackay, H. M. M., Henderson Smith, H. \& Wimberger, H. (1923). Spec. Rep. Ser. med. Res. Coun. no. 77, p. 19.

Cook, J., Altman, D. G., Moore, D. M. C., Topp, S. G., Holland, W. W. \& Elliott, A. (1973). Br. Y. prev. soc. Med. 27, 91.

Department of Health \& Social Security (Ig6g). Rep. Publ. Hlth med. Subj., Lond. no. 120. Department of Health \& Social Security (1970). Rep. Publ. Hlth med. Subj., Lond. no. 123. Department of Health \& Social Security \& Office of Population Censuses and Surveys (1970). Report on Hospital In-Patient Enquiry for the Year 1967. London: H.M. Stationery Office. 
Department of Health \& Social Security and Office of Population Censuses and Surveys (1974). Report on Hospital In-Patients Enquiry for the Year 1972. London: H.M. Stationery Office.

Dick, J. L. (1922). Rickets. London: Heinemann.

Dunnigan, M. G. \& Smith, C. M. (1965). Scott. med. F. 10, I.

Findlay, L. \& Ferguson, M. (1918). Spec. Rep. Ser. med. Res. Coun. no. 20.

Ford, J. A., Colhoun, E. M., McIntosh, W. B. \& Dunnigan, M. G. (1972). Br. med. J. iii, 446.

Glisson, F. (1650). De rachitide Sive Morbo Puerili, qui Vulgo The Rickets Dicitur. London: F. Glisson.

Guignard, J., Belkziz, O. \& Belhaj, A. (1971). Bull. Acad. natn. Méd. 155, 662.

Gupta, M. M., Round, J. M. \& Stamp, T. C. B. (1974). Lancet i, 586.

Holmes, A. M., Enoch, B. A., Taylor, J. L. \& Jones, M. E. (1973). Q. Il Med. 42, 125.

King, E. J. \& Armstrong, A. R. (1934). Can med. Ass. f. 3r, 376.

Mellanby, E. (1921). Spec. Rep. Ser. med. Res. Coun. no. 61.

Ministry of Health (1968). Rep. Publ. Hlth med. Subj., Lond. no. I 8.

National Food Survey Committee (1970). Household Food Consumption and Expenditure, 1968. London: H.M. Stationery Office.

Owen, I. (1889). Br. med. F. i, II 3 .

Palm, T. A. (1890). Practitioner 45, 270.

Richards, I. D. G., Hamilton, F. M. W., Taylor, E. C., Sweet, E. M., Bremner, E. \& Price, H. (1968). Scott. med. $\mathcal{~} .13,297$.

Ruck, N. (1973). Proc. Nutr. Soc. 33, i7A.

Salimpour, R. (1975). Archs Dis. Childh. 50, 63.

Stephen, J. M. L. \& Stephenson, P. (1971). Archs Dis. Childh. 46, 185.

Stroud, C. E. (1971). Br. F. Hosp. Med. 5, 629 .

Vaishnava, H. P. \& Rizvi, S. N. A. (1967). Br. med. F. i, I1 2.

Waterlow, J. C., Cravioto, J. \& Stephen, J. M. L. (1960). Ado. Protein Chem. 15, I3I.

Waterlow, J. C. \& Vergara, A. (1956). Bull. Wld Hlth Org. 15, 165.

Williams, C. D. (1933). Archs Dis. Childh. 8, 423.

Wilson, D. C. \& Widdowson, E. M. (1942). Indian 7. med. Res. Mem. no. 34. 